\title{
PATHOLOGICAL STUDIES OF MODIFIED PNEUMOCONIOSIS IN COAL-MINERS WITH RHEUMATOID ARTHRITIS (CAPLAN'S SYNDROME)
}

\author{
BY \\ J. GOUGH, D. RIVERS, AND R. M. E. SEAL \\ From the Department of Pathology and Bacteriology, Welsh National School of Medicine, Cardiff
}

(RECEIVED FOR PUBLICATION DECEMBER 8, 1954)

In 1953 Caplan, of the Cardiff Pneumoconiosis Medical Panel, recorded that massive pneumoconiosis was commoner in coal-workers suffering from rheumatoid arthritis than in those not subject to this condition. He also noticed that the radiological opacities in some of these arthritics had distinctive features which enabled him to distinguish them from the usual forms of massive fibrosis. The distinctive shadows were multiple, round, well defined and distributed fairly evenly throughout both lung fields, particularly at the periphery. Not all arthritics showed these changes and in many the lesions appeared radiologically to be the usual massive fibrosis, tuberculosis, or a combination of these.

In those instances where radiographs had shown little or no evidence of pre-existing pneumoconiosis the characteristic findings in the rheumatoid cases were circumscribed opacities. When, however, the category of pneumoconiosis had been higher there was a greater tendency for the development of what appeared in the radiographs to be ordinary massive fibrosis.

The present paper is an account of the morbid anatomy, histology, and bacteriology of cases of this syndrome. We have examined the lungs obtained at necropsy in 14 Welsh coal-miners with rheumatoid arthritis and biopsy lung specimens from two additional cases. Seven of these 16 miners had shown the circumscribed radiological opacities described by Caplan. In five others there were suggestive but not diagnostic round opacities. Three of these latter five cases also showed massive fibrosis in the radiographs.

The lung lesions were found to be a modified form of pneumoconiosis associated in several cases with proved tuberculosis. In a few instances, however, there was an active inflammation which could not be proved to be tuberculous. This inflammation may have been modified tuberculosis, but because of the failure to find tubercle bacilli in these instances they are considered as possibly "rheumatoid" in origin. The inflammation was non-specific. There were certain naked-eye appearances which distinguished the lesions from the usual forms of pneumoconiosis and these differences could be well seen in paper-mounted whole sections of the lungs. They consisted of an exaggeration of certain of the features of infective pneumoconiosis. Before describing these appearances a summary will be given of the present concept of the aetiology and character of the various forms of pneumoconiosis usually met with in coalworkers. The usual forms will be referred to as orthodox changes to distinguish them from the changes in the rheumatoid cases.

\section{ORthodox PNeUmoconiosis}

In the small percentage of coal-miners working on rock, classical silicosis develops, but in those who work on the coal seams and those engaged in loading and transporting coal characteristic lesions develop which have been called coal nodules. These lesions are stellate and intensely black. They contain comparatively little fibrous tissue, which usually consists only of reticulin, but in some instances the coal nodules develop a little collagen, which is not dense or concentrically arranged but is disposed irregularly or with some tendency to radial arrangement. These foci are scattered throughout the lung and reach a size of up to about $5 \mathrm{~mm}$. In and around these foci emphysema develops. In the majority of coalworkers no further development takes place, but in many there is super-imposed upon this simple pneumoconiosis well-marked collagenous fibrosis ranging from masses up to about $15 \mathrm{~cm}$. in diameter down to nodules $\frac{1}{2} \mathrm{~cm}$. in diameter. Both the masses and fibrous nodules seem to represent a similar process and tuberculosis is regarded as playing a part in their formation. The nodules have, therefore, been called "infective 


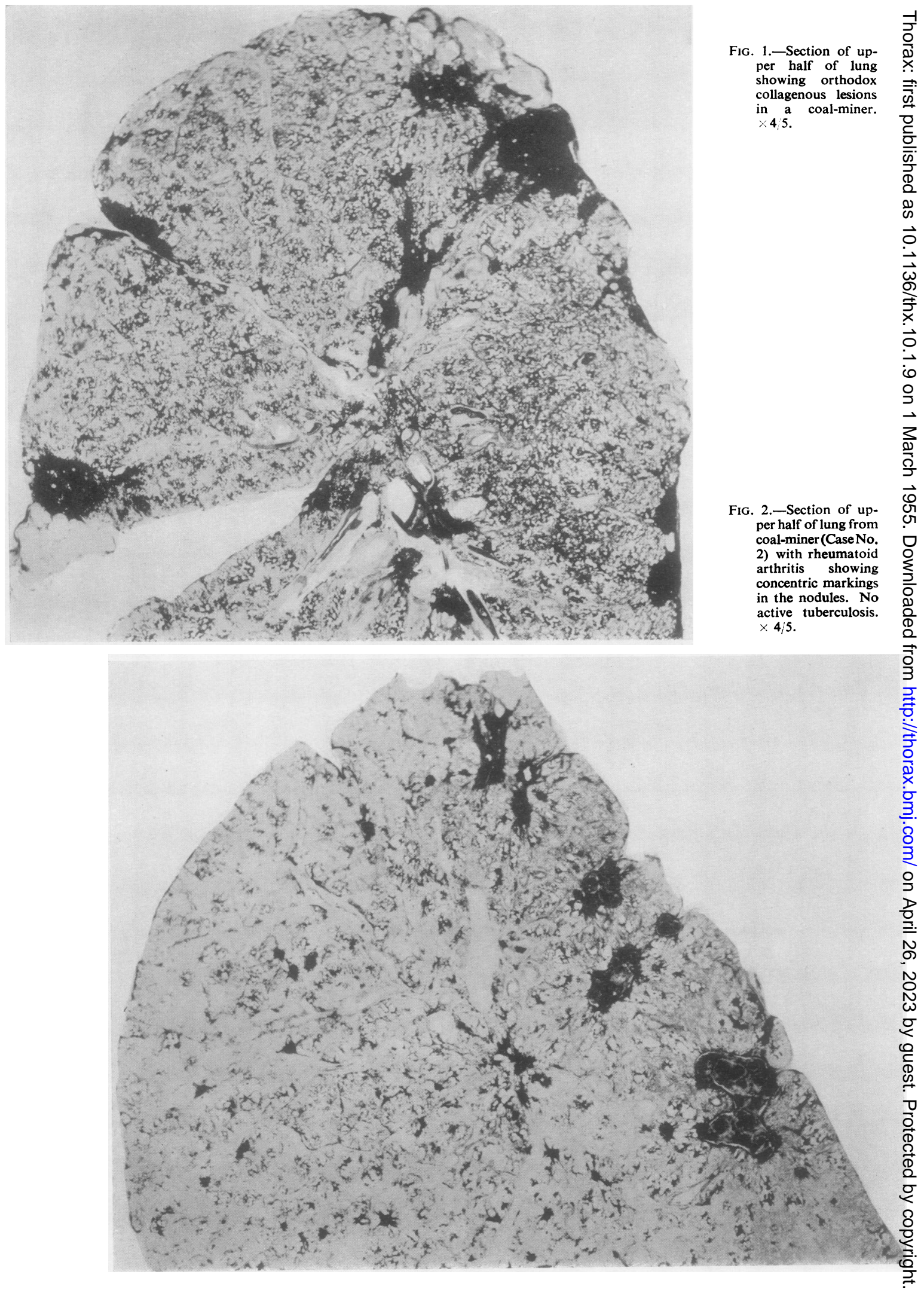


FiG. 3. - Section of left lung from coal-miner with rheumatoid arthritis( Case No. 15 ) showing discrete and confluent nodules. $\times 4 / 5$.

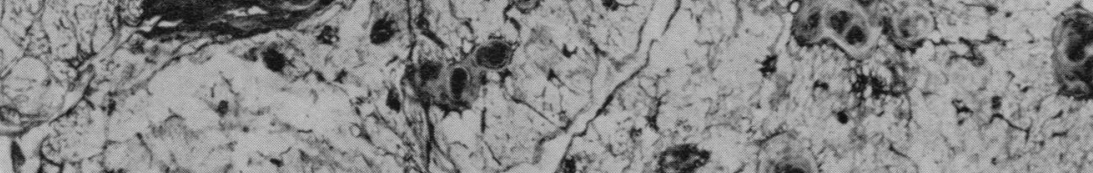

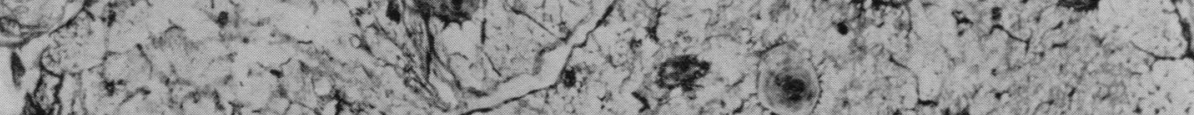
2.

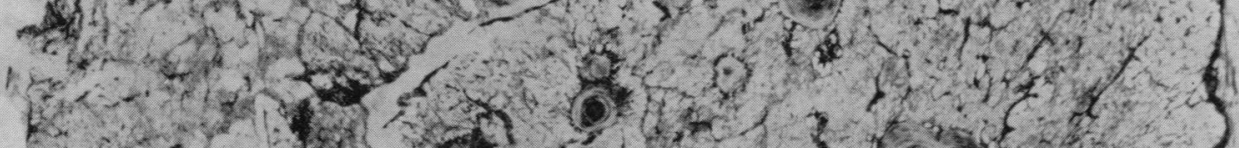

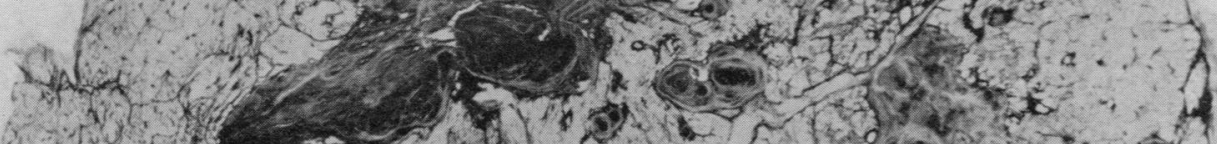

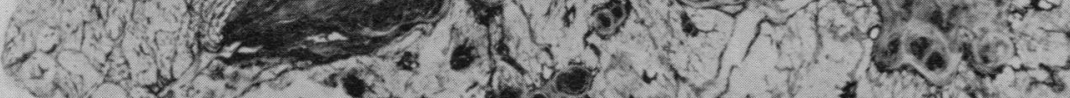

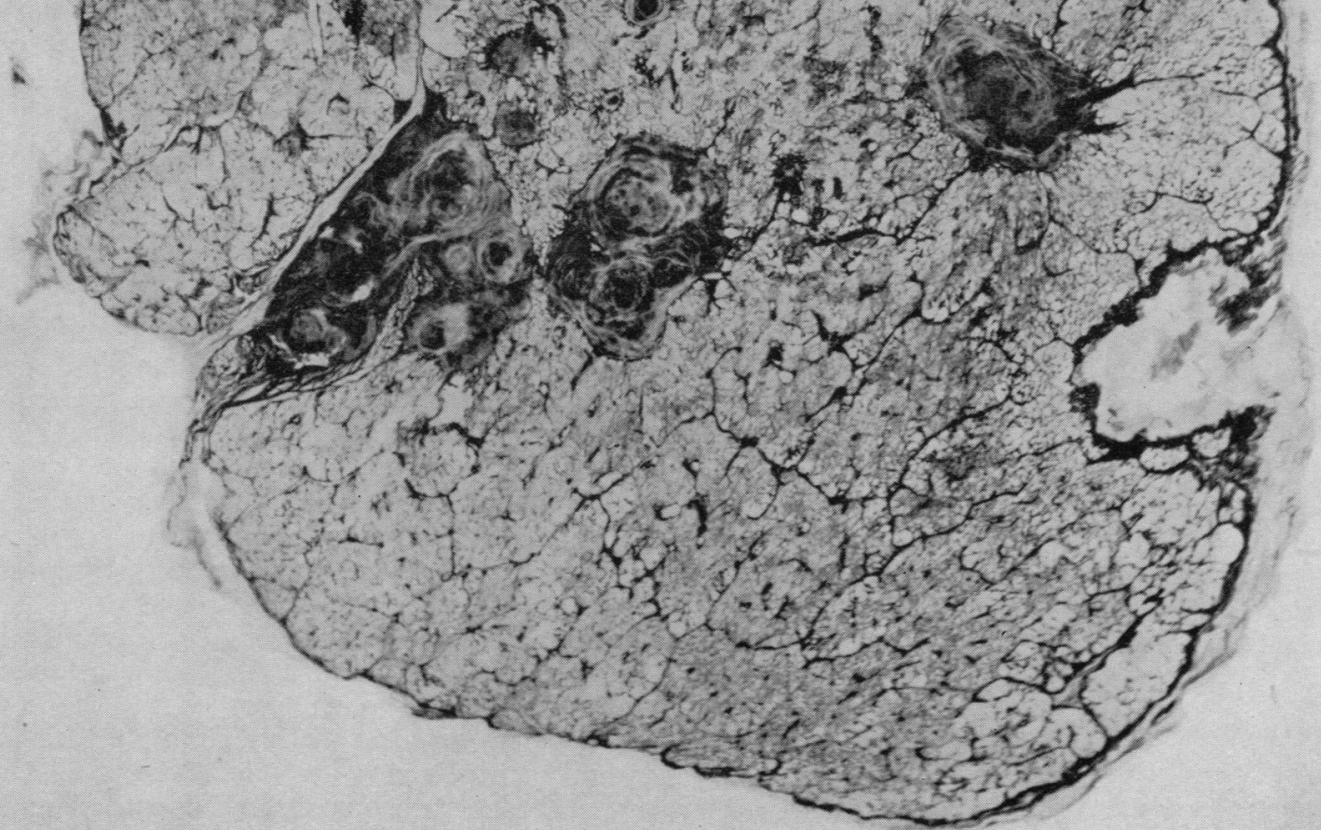


nodules." We will refer to these masses and infective nodules as "collagenous" lesions to distinguish them from foci of simple pneumoconiosis which contain mainly reticulin.

Orthodox collagenous nodules may be few or numerous. They are often satellite to a big fibrous mass, but may be distributed in various parts of the lung. They may, however, be found scattered in different parts of the lung in the absence of large masses (Fig. 1). They are commonest in the upper lobes and may occur both in the interior of the lung and beneath the pleura. They are jet black, but on close inspection some show a faint grey filigree or faintly grey centres. When there is active tuberculosis the nodules often show a concentric arrangement of darker and lighter areas. We may mention in anticipation that it is an exaggeration of a similar appearance that characterizes the gross structure of the "rheumatoid" lung lesions (Fig. 2).

Histologically the orthodox collagenous lesions may or may not show evidence of tuberculosis. The latter is frequently recognizable by the characteristic follicles, but sometimes the tuberculous reaction is modified. In such cases there are no follicles and no giant cells but only a nonspecific inflammatory reaction consisting of polymorphonuclear leucocytes and macrophages, but in such cases tubercle bacilli can usually be found by culture or on guinea-pig inoculation. In many miners the collagenous lesions show no active inflammation. Most of these indolent lesions, however, contain much necrotic collagen, but there is little or no cellular reaction except for the development of collections of lymphocytes at the periphery. Blood vessels are largely destroyed in the interior of the lesions and there is endarteritis in vessels at the periphery. A large amount of dust is present in these indolent lesions, the bulk of it lying free in the tissue. The dust is often in the form of lines and circles representing columns of dead phagocytes. The mode of formation of these lines and circles is readily seen when active tuberculosis is present, as fibroblastic cells at the edge of necrotic material are arranged in parallel formation and contain dust. In the indolent lesions the lines and circles of dust apparently indicate a former active tuberculosis.

\section{"Rheumatoid" Pneumoconiotic Lesions}

These had a similar distribution in the lung to orthodox lesions. In some instances there were masses in the upper parts of the lungs and discrete nodules elsewhere (Fig. 3) and in others there were no masses but only discrete nodules. In some cases the nodules were few and in others numerous. The masses could be seen to be made up mainly of confluent large nodules. In the masses, however, there were cavities due to active or in some instances apparently healed tuberculosis. In section the nodules were round or oval in outline. They were not uniformly impregnated with dust but showed a characteristic concentric arrangement of lighter and darker layers. The paler areas were in some instances grey and in others yellow. They had the appearance which is seen when active tuberculosis is present with pneumoconiosis, but they were bigger and the concentric zones were wider than in orthodox cases. Liquefaction tended to occur in the pale areas leaving clefts (Fig. 4). In some cases the nodules were densely calcified. Most nodules up to $\frac{1}{2} \mathrm{~cm}$. in diameter and some bigger ones showed a single system of concentric layers. Large nodules were, however, usually composite and made up of several nodules with a common outer fibrous capsule (Fig. 5). These appearances occur in silicosis (Simson, 1935) and to the naked eye some of the "rheumatoid" lesions looked like giant silicotic nodules, but it was seen histologically that they were unlike classical silicosis. They could best be described as unusually large forms of collagenous nodules with what appeared to the naked eye to be active tuberculosis. In more than half the cases, however, the presence of active tuberculosis could not be proved. Amongst the large nodules there were occasional small ones made up entirely of pale yellow material, but this appearance was due to tangential cutting through a pale peripheral zone of a large nodule. The background of simple pneumoconiosis in these cases was slight or moderate and its degree bore no relation to the severity of the nodular and confluent fibrosis.

Histologically the "rheumatoid" pneumoconiotic lesions had in the main the same com- 을 ponents as orthodox collagenous ones. Necrotic N tissue containing various amounts of collagen made up the central bulk. Few nuclei were to be recognized in this necrotic mass. There was $\underset{\omega}{ }$ a greater tendency, however, to calcification of the necrotic tissue in the "rheumatoid" nodules. 0 Dust was present and lying free and often in lines $\stackrel{D}{\Phi}$ and circles similar to those in the orthodox cases $\stackrel{?}{?}$ (Fig. 6). The outer part of the lesion showed 0 collagen arranged mainly circumferentially. This collagen was not necrotic. The fibroblasts next $\stackrel{\mathbb{Q}}{\mathbb{Q}}$ to the necrotic mass showed palisading in some $\mathbb{\mathbb { Q }}$ but not all cases. Palisading was not a pro- $\bar{O}$ nounced feature (Fig. 7). Associated with the 


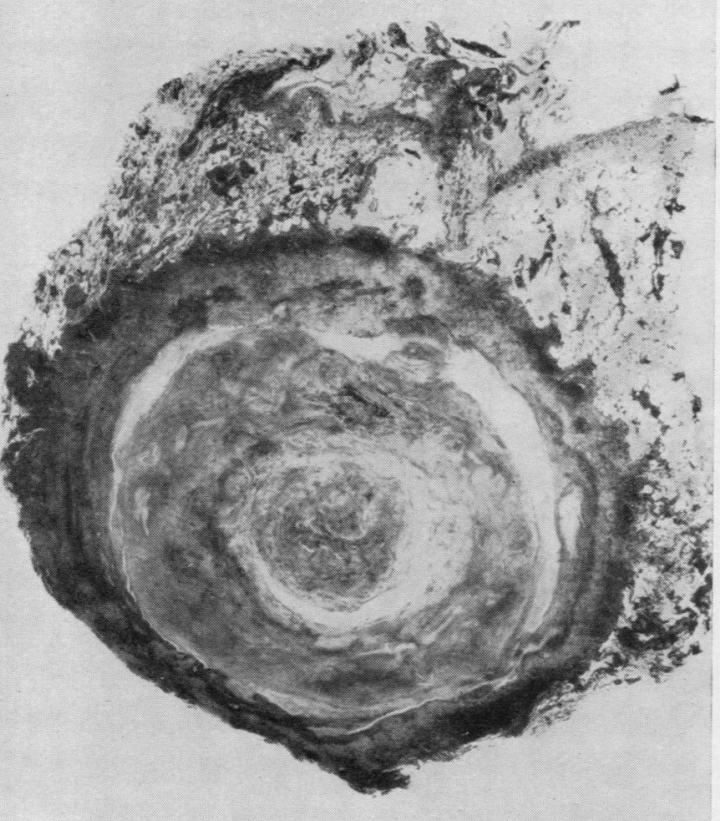

Fig. 4.- " Rheumatoid" pneumoconiotic nodule showing concentric structure with formation of clefts. No active tuberculosis. $\times 4$.

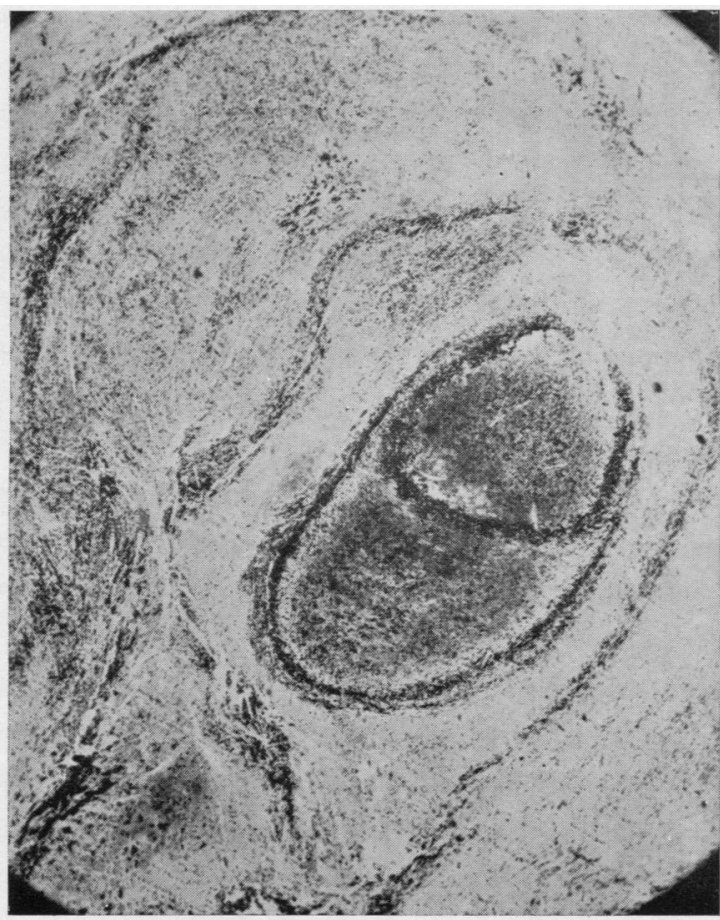

FIG. 6. - Lines of stranded dust in a " rheumatoid" pneumoconiotic nodule. $\times 30$.

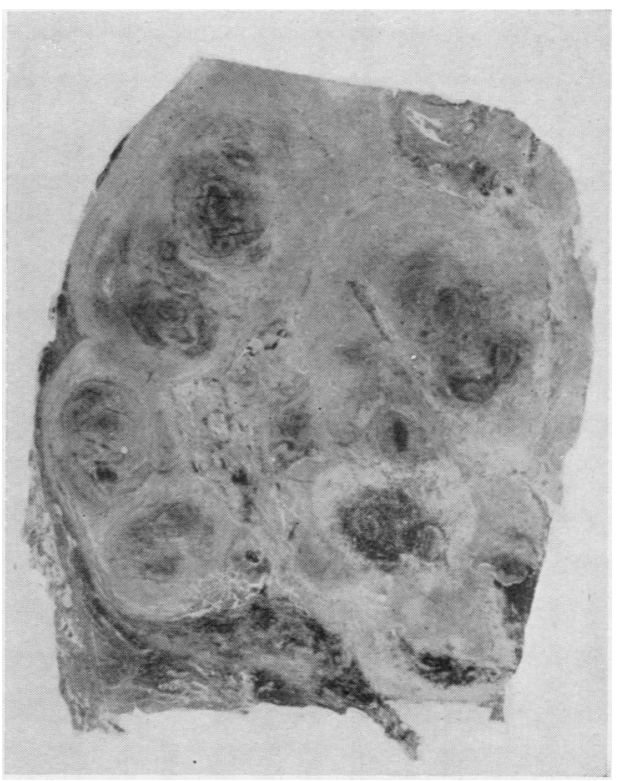

FIG. 5.-Composite " rheumatoid" pneumoconiotic nodule. $\times 4 \frac{1}{2}$.

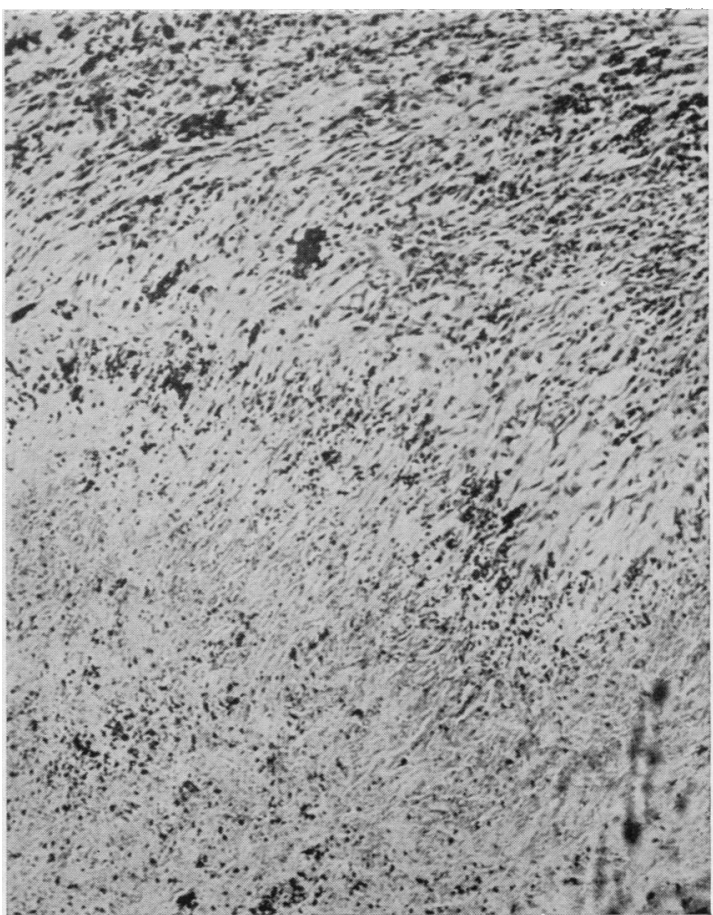

FIG. 7.-Palisade of fibroblasts in a "rheumatoid" pneumoconiotic nodule. This feature was not consistently present. Haematoxylin and eosin. $\times 100$. 
outer collagen layer were lymphoid collections which in a few instances were more numerous and larger than in orthodox cases and they had germ centres, but these lymph collections were not sufficiently different from those in the orthodox lesions to be distinctive.

Special stains for fibrinoid were not very helpful in the interpretation of the lesions. Fibrinoid necrosis occurs in the orthodox as well as in "rheumatoid" lesions, and the periodic-acidSchiff staining was faint in both types of lesion. In no instance was periodic-acid-Schiff staining as strong as in subcutaneous rheumatoid nodules. An investigation by special staining is being continued.

Obliteration of blood vessels in the necrotic centre and endarteritis in those at the periphery differed from the orthodox lesions in that within the obliterated lumina of the vessels in the "rheumatoid" cases the cells contained less dust and there were more lymphocytes and plasma cells.

Several of the "rheumatoid" cases showed tuberculosis recognizable histologically. In at least half of the 16 cases, however, there was an

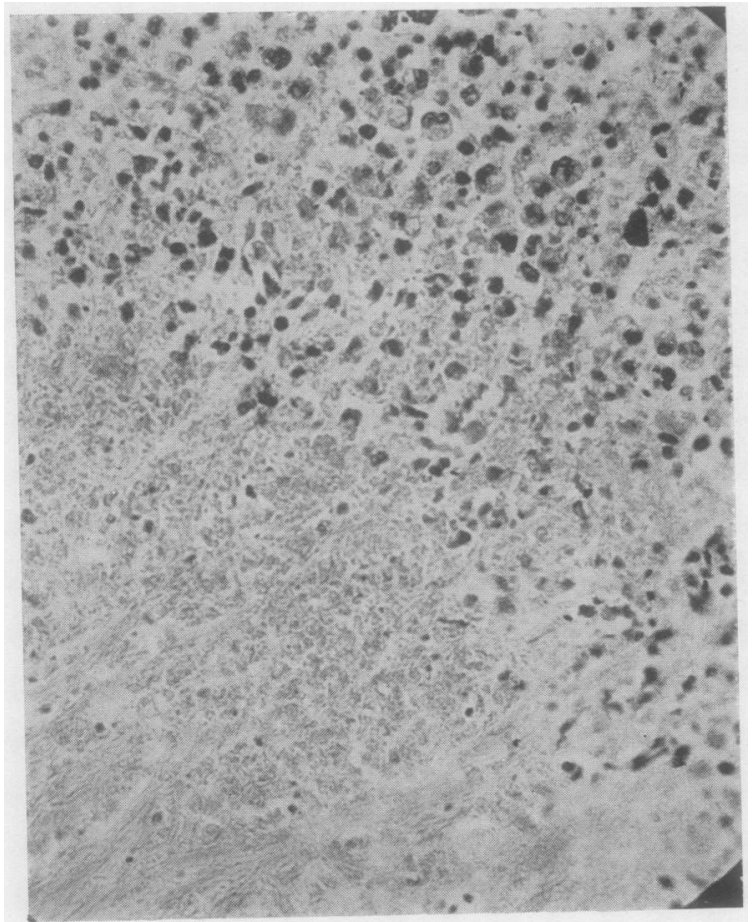

Fig. 8.-Infiammatory zone, from periphery of a " rheumatoid" pneumoconiotic nodule. Haematoxylin and eosin. $\times 400$. active inflammation which histologically did not resemble tuberculosis. In trying to determine whether this inflammation may have been of "rheumatoid" origin particular attention was directed to those cases showing the inflammation but in which guinea-pig inoculation had proved to be negative for tubercle bacilli. There were four such cases and in each the inflammation was similar. Within the outer collagenous layer was a zone usually circumferentially arranged containing polymorphonuclear leucocytes and a few macrophages and abutting on the central mass of collagen (Fig. 8). This zone extended partly or completely around the nodules, and many of the cells in it were disintegrating. With haematoxylin and eosin the inflammatory zone stained blue and so contrasted with the central mass of pink necrotic collagen. The central collagen ended abruptly, the fibres appearing as if they had broken off where they were in contact with the inflammatory cells (Fig. 9). The "rheumatoid" pneumoconiotic nodules, therefore, differ from the orthodox collagenous nodules in having this peripheral zone of active inflammation.

FIG. 9.-Abrupt ending of collagen showing fibrinoid necrosis if "rheumatoid" pneumoconiotic nodule. Phosphotungstic aci haematoxylin. $\times 250$. 


\section{BACTERIOLOGY}

The overall evidence of tuberculosis in the series was :

NeCropsy CASES.-Of a total of 14, guinea-pig inoculation was positive in two, negative in eight. Of the remaining four cases, histological evidence of tuberculosis was definite in one, probable in two. A total of three certain and two probable cases of tuberculosis out of 14 approximates what we would have expected to find if these had been orthodox cases of pneumoconiosis. Excluding Case No. 4, which had no nodules and slight simple pneumoconiosis, the probable incidence of tuberculosis is approximately $40 \%$, which is the same as is found in orthodox lesions. One case (No. 11) had a positive sputum for tuberculosis one year before death, but guinea-pig examination at necropsy was negative.

Biopsy CASES.-One was examined by culture and guinea-pig inoculation with negative results.

TABLE I

\begin{tabular}{|c|c|c|c|c|c|c|c|}
\hline $\begin{array}{l}\text { Case } \\
\text { No. }\end{array}$ & Age & $\begin{array}{l}\text { Dust } \\
\text { Exposure } \\
\text { in Coal- } \\
\text { Mines } \\
\text { (Years) }\end{array}$ & $\begin{array}{l}\text { Evidence of } \\
\text { Tuberculosis }\end{array}$ & $\begin{array}{l}\text { Duration of } \\
\text { Arthritis } \\
\text { (Years) }\end{array}$ & $\begin{array}{l}\text { Radiographic } \\
\text { Appearances }\end{array}$ & Lung Lesions & Cause of Death \\
\hline 1 & 52 & 22 & $\begin{array}{l}\text { Guinea-pig negative } \\
\text { on lung tissue }\end{array}$ & At least 3 & $\begin{array}{l}\text { Characteristic dis- } \\
\text { crete opacities }\end{array}$ & Characteristic nodules & $\begin{array}{l}\text { Cardiac failure } \\
\text { Aortic stenosis }\end{array}$ \\
\hline 2 & 61 & 43 & $\begin{array}{l}\text { Guinea-pig negative } \\
\text { on lung tissue }\end{array}$ & 6 & $\begin{array}{l}\text { Characteristic dis- } \\
\text { crete opacities }\end{array}$ & Characteristic nodules & $\begin{array}{l}\text { Pneumoconiosis } \\
\text { Uraemia } \\
\text { Amyloid disease }\end{array}$ \\
\hline 3 & 73 & 35 & $\begin{array}{l}\text { Guinea-pig negative } \\
\text { on lung tissue }\end{array}$ & At least 12 & $\begin{array}{l}\text { P.M.F. + a few round } \\
\text { opacities }\end{array}$ & $\begin{array}{l}\text { Characteristic nodules } \\
\text { Confluent }\end{array}$ & $\begin{array}{l}\text { Pneumoconiosis } \\
\text { Cor pulmonale } \\
\text { Bed sores }\end{array}$ \\
\hline 4 & 59 & 38 & $\begin{array}{c}\text { No guinea-pig or cul- } \\
\text { ture examination. } \\
\text { No histological evi- } \\
\text { dence of tuberculosis }\end{array}$ & Many & $\begin{array}{l}\text { Early simple pneumo- } \\
\text { coniosis } 4 \text { years } \\
\text { before death. No } \\
\text { radiograph after- } \\
\text { wards }\end{array}$ & $\begin{array}{l}\text { No characteristic } \\
\text { nodules } \\
\text { Orthodox pneumo- } \\
\text { coniosis }\end{array}$ & $\begin{array}{l}\text { Cor pulmonale } \\
\text { Emphysema }\end{array}$ \\
\hline 5 & 53 & 25 & $\begin{array}{l}\text { Guinea-pig negative } \\
\text { on lung tissue }\end{array}$ & 3 & $\begin{array}{l}\text { Massive fibrosis. This } \\
\text { preceded arthritis }\end{array}$ & $\begin{array}{l}\text { Characteristic nodules } \\
\text { Confluent }\end{array}$ & $\begin{array}{l}\text { Pneumoconiosis } \\
\text { Cor pulmonale }\end{array}$ \\
\hline 6 & 46 & $\begin{array}{l}15 \\
\text { Collier }\end{array}$ & $\begin{array}{l}\text { Guinea-pig and cul- } \\
\text { ture positive on } \\
\text { lung tissue }\end{array}$ & 13 & $\begin{array}{l}\text { P.M.F. poor film. } \\
\text { ? cavities mid-zone }\end{array}$ & $\begin{array}{l}\text { Some characteristic } \\
\text { nodules of small } \\
\text { size }\end{array}$ & Cerebral haemorrhage \\
\hline 7 & 29 & 13 & $\begin{array}{l}\text { Guinea-pig positive in } \\
\text { lung tissue }\end{array}$ & 2 & $\begin{array}{l}\text { Fairly characteristic. } \\
\text { P.M.F. Some } \\
\text { round opacities }\end{array}$ & $\begin{array}{l}\text { Pneumoconiosis and } \\
\text { active tuberculosis }\end{array}$ & $\begin{array}{l}\text { Pneumoconiosis } \\
\text { Pulmonary tuberculosis } \\
\text { Haemoptysis }\end{array}$ \\
\hline 8 & 47 & $\begin{array}{l}\text { Collier } \\
\text { up to } \\
\text { age } 42\end{array}$ & $\begin{array}{l}\text { Histology suggestive } \\
\text { of modified tuber- } \\
\text { culosis. No guinea- } \\
\text { pig examination }\end{array}$ & 13 & $\begin{array}{l}\text { Characteristic dis- } \\
\text { crete opacities }\end{array}$ & $\begin{array}{l}\text { Characteristic nodules } \\
\text { Confluent }\end{array}$ & $\begin{array}{l}\text { Pneumoconiosis } \\
\text { Amyloid disease }\end{array}$ \\
\hline 9 & 55 & 28 & $\begin{array}{l}\text { No guinea-pig exam- } \\
\text { ination or culture }\end{array}$ & 10 & $\begin{array}{l}\text { Cat. } 1 \text { simple pneu- } \\
\text { moconiosis }\end{array}$ & $\begin{array}{l}\text { No characteristic } \\
\text { nodules }\end{array}$ & Coronary occlusion \\
\hline 10 & 72 & 25 & $\begin{array}{l}\text { Guinea-pig negative } \\
\text { on lung tissue }\end{array}$ & 27 & $\begin{array}{c}\text { Characteristic discrete } \\
\text { opacities }\end{array}$ & Characteristic & $\begin{array}{l}\text { Cardiac failure due to } \\
\text { pneumoconiosis }\end{array}$ \\
\hline 11 & 55 & 34 & $\begin{array}{l}\text { Positive sputum } 1 \text { year } \\
\text { before death. Cul- } \\
\text { ture and guinea-pig } \\
\text { negative on lung } \\
\text { tissue }\end{array}$ & 1 & $\begin{array}{l}\text { Not characteristic but } \\
\text { suggestive }\end{array}$ & $\begin{array}{l}\text { Not characteristic } \\
\text { Suggestive }\end{array}$ & $\begin{array}{l}\text { Pneumoconiosis } \\
\text { Bronchitis }\end{array}$ \\
\hline 12 & 50 & 27 & $\begin{array}{l}\text { Definite tuberculosis } \\
\text { histologically }\end{array}$ & $\begin{array}{l}\text { Definite arthritis } \\
\text { but duration } \\
\text { not known }\end{array}$ & $\begin{array}{l}\text { P.M.F. 1952. 1946, } \\
\text { Cat. 3 B. A few } \\
\text { round opacities }\end{array}$ & $\begin{array}{l}\text { Nodules suggestive } \\
\text { but not fully devel- } \\
\text { oped }\end{array}$ & $\begin{array}{l}\text { Pneumoconiosis } \\
\text { Pulmonary tuberculosis }\end{array}$ \\
\hline 13 & 72 & 53 & $\begin{array}{l}\text { No guinea-pig exam- } \\
\text { ination. No histo- } \\
\text { logical evidence of } \\
\text { tuberculosis }\end{array}$ & Many & $\begin{array}{l}\text { Not diagnostic. Not } \\
\text { typical. Cat. } 3 \text { but } \\
2 \text { round opacities } \\
\text { at base }\end{array}$ & $\begin{array}{l}\text { Orthodox collagenous } \\
\text { nodules. A few } \\
\text { characteristic } \\
\text { nodules }\end{array}$ & $\begin{array}{l}\text { Hypertension } \\
\text { Cerebral softening }\end{array}$ \\
\hline 14 & 47 & 35 & $\begin{array}{l}\text { No definite histologi- } \\
\text { cal evidence. No } \\
\text { guinea-pig exam- } \\
\text { ination }\end{array}$ & 5 & $\begin{array}{l}\text { Characteristic dis- } \\
\text { crete opacities }\end{array}$ & $\begin{array}{l}\text { Biopsy } \\
\text { Characteristic nodules }\end{array}$ & Still alive \\
\hline 15 & 69 & 46 & $\begin{array}{l}\text { Histology suggestive } \\
\text { of tuberculosis in a } \\
\text { few nodules only }\end{array}$ & 6 & $\begin{array}{l}\text { Characteristic. Rapid } \\
\text { development of } \\
\text { opacities } 5 \text { years } \\
\text { before death }\end{array}$ & $\begin{array}{l}\text { Characteristic nodules } \\
\text { Confluent }\end{array}$ & $\begin{array}{l}\text { Carcinoma of prostate } \\
\text { Secondaries in spine }\end{array}$ \\
\hline 16 & 52 & 36 & $\begin{array}{l}\text { Guinea-pig negative. } \\
\text { Culture negative }\end{array}$ & $1 \frac{1}{2}$ & $\begin{array}{l}\text { Characteristic dis- } \\
\text { crete opacities }\end{array}$ & $\begin{array}{l}\text { Biopsy } \\
\text { Characteristic nodules }\end{array}$ & Still alive \\
\hline
\end{tabular}


The other showed no definite histological evidence of tuberculosis.

Details of the cases are set out in Table I. The radiographs were examined by Dr. Caplan, and his reports are given. In the cases in which he described characteristic round opacities we found characteristic "rheumatoid" pneumoconiotic nodules. We also found them associated with massive fibrosis in two cases where the radiographs had shown apparently only massive fibrosis.

In two cases (Nos. 4 and 9) with arthritis there were no rheumatoid nodules in the lungs but only orthodox pneumoconiosis.

In two cases (Nos. 7 and 12) with active tuberculosis the nodules were forming but were not fully developed.

As would be expected, the causes of death in the fatal cases were quite different from those usually found in sufferers from rheumatoid arthritis, but there was one similarity: there were two cases with severe amyloid disease. Most, however, died of their pneumoconiosis either due to cardiac failure or tuberculosis. We might mention that in a series of 30 cases of rheumatoid arthritis recorded by Rosenberg, Baggenstoss, and Hench (1944) there was no death due to tuberculosis.

\section{Discussion}

Corresponding with the distinctive round opacities seen in chest radiographs of miners with rheumatoid arthritis there are fairly characteristic pneumoconiotic lesions. These are at least distinctive in gross appearance. We cannot, however, point to any histological feature in them that is specifically " rheumatoid."

The great difficulty is that tuberculosis, sometimes in a modified form, is commonly present in coal workers' pneumoconiosis, and it was present in several cases in the present series. In such lungs it would be difficult to recognize a "rheumatoid component" unless the latter had specific histological features. There was not, for instance, the pronounced palisading of mesenchymal cells such as is seen in subcutaneous nodules. Some palisading of fibroblasts was present, but this was not definitely distinguishable from that seen in tuberculous lesions. Kellgren and Ball (1950) found in rheumatoid lesions of tendons that palisading was by no means a constant finding. Our only evidence of a possible "rheumatoid" lesion was a non-specific inflammation within the nodules in some cases in which guinea-pig inoculation for tuberculosis was negative. This non-specific inflammatory zone may be the "rheumatoid" component. We recognize the need to interpret the lesions cautiously, as tuberculosis is often modi $-\overrightarrow{\vec{F}}$ fied in pneumoconiotic lungs. In orthodox cases $\stackrel{?}{?}$ of pneumoconiosis, however, when tuberculosis? was suspected histologically, the guinea-pig test $\frac{\bar{O}}{\bar{N}}$ was rarely negative. We regard as very signifi- $\frac{?}{2}$ cant the finding of negative guinea-pig tests in four $\stackrel{\odot}{\varrho}$ rheumatoid cases showing a peripheral zone of $ळ$ active inflammation. These four cases included $\vec{\theta}$ one in which nodules were obtained by biopsy. Both guinea-pig inoculation and culture were nega- $\vec{\omega}$ tive for tubercle bacilli in that case. We do not $\stackrel{\rho}{\circ}$ place much emphasis on negative findings in $\overrightarrow{\vec{x}}$ Ziehl-Neelsen-stained sections, but many hours of $\overrightarrow{-}$ searching did not show acid-fast bacilli in these cases. We may mention that it is not a charac- 6 teristic of ordinary pneumonias to extend into 을 pneumoconiotic nodules.

If it is accepted that the "rheumatoid" lung lesions represent a modified form of infective $\bar{\alpha}$ pneumoconiosis then there are several possible explanations for the abnormal reaction.

First, it may be an unusual reaction to the dust alone. This does not, however, appear to be likely, since foci of simple pneumoconiosis packed with dust-filled phagocytes may remain unaltered side by side with " rheumatoid" lesions (Fig. 10). The lesions are certainly not related to the total quan- $\mathbb{D}$ tity of dust, as several severe cases showed com- $\vec{F}$ paratively little dust. On simple microscopy we saw nothing unusual in the character of the dust. It was the usual type characteristic of coal-mining. When tuberculosis supervenes in pneumoconiosis, dust-laden phagocytes are killed and the dust is free and so may then exert a different action. These miners did not show classical silicosis, but $\underset{-}{-}$ similar radiological pictures as those described by 3 Caplan have been found in relation to a silica $\delta$ hazard (Colinet, 1950 and 1953). Pathological studies in such cases are still awaited.

Secondly, it may be an altered reaction to tuberculosis, since the latter appears to play a part in the formation of the collagenous lesions in coal-miners. Nevertheless, even if tubercu- $\sigma$ losis is present $a b$ initio an active inflammation $N$ persists in some "rheumatoid" cases where no 응 tubercle bacilli could be found.

Finally, if we seek analogy with " rheumatoid" lesions in the subcutaneous tissues and tendons these latter of course do not contain dust, and $\stackrel{\oplus}{\oplus}$ tuberculosis either locally or elsewhere is rarely associated with them. The only common factor 0 which seems obvious is the presence of collagen $\mathbb{D}$ undergoing necrosis. In orthodox pneumoconiotic $\frac{\vec{D}}{\mathbb{D}}$ cases and when there is no evidence of tubercu- $\frac{\varrho}{\square}$ losis the necrotic collagen does not excite peri- 
pheral active inflammation, whereas such inflammation is present in the rheumatoid cases when active tuberculosis seemed to be absent.

The necrotic collagen in the lung lesions is not the preformed connective tissue of the lung but action resulting from necrotizing lesions involving collagen.

In ordinary cases of rheumatoid arthritis nodular lesions are rare in the lung although an example has been described by Ellman, Cudkowicz, and

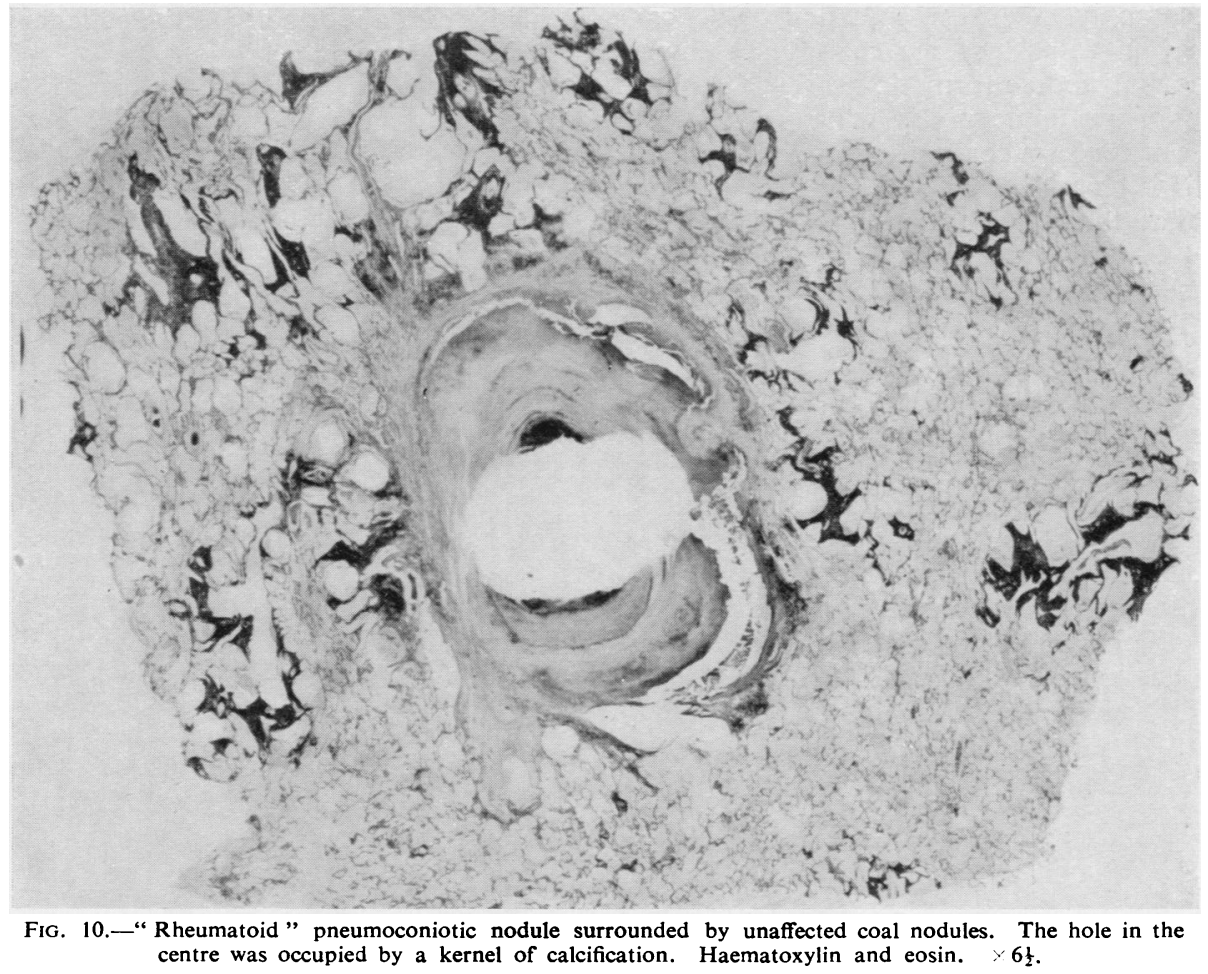

newly formed as a result of the infective pneumoconiotic process. Several investigators have concluded that the basic lesion in rheumatoid disease is necrosis of granulation tissue and not necrosis of pre-existing normal tissue. Collins (1937) came to this conclusion in an investigation of subcutaneous nodules, and Gruenwald (1948) from a study of a case in which the heart pleura and other organs were involved. Kellgren and Ball (1950) found on investigation of tendon lesions that the latter contained necrotic collagen affecting not only the original connective tissue of the tendons but also newly formed connective tissue in the nodules. Indeed, these latter authors regard necrosis of collagen as perhaps the fundamental change and say that at least one form of genesis of the tendon lesions is a focal fibrinoid degeneration of non-specific granulation tissue.

The findings in coal-miners' lungs lend support to the view (Kellgren, 1952) that rheumatoid disease is fundamentally an inflammatory re-
Elwood (1954). It is significant that they found in the nodules softened zones containing cells suggestive of degenerating polymorphs and that the periodic-acid-Schiff reaction was relatively weak. These changes would appear to correspond with the " rheumatoid " component in the coal-miners' lungs. Christie (1954) describes three cases with pulmonary lesions including nodule formation. $\mathrm{He}$ noted secondary invasion of polymorphonuclear leucocytes and resulting liquefaction. In one of his cases there was a giant nodule $7 \mathrm{~cm}$. in diameter. The occupation was not stated in the account of these cases.

In contrast to ordinary lungs the pneumoconiotic lung of coal-miners appears very vulnerable to the "rheumatoid process." Indeed, the lungs are sometimes more vulnerable than the joints. Miall, Caplan, Cochrane, Kilpatrick, and Oldham (1953) have shown that the characteristic radiographic appearances in the chest may precede by many years the development of joint lesions. We also 
have at least one case in which the radiographs and lung lesions seem characteristic of the "rheumatoid" pneumoconiotic type, but there were no joint changes.

A commonly accepted view is that rheumatoid disease results from an unusual reaction to perhaps a commonly occurring infection. We can certainly say in respect of the coal-miners' lungs that the peculiar nodule formations are a variation of a form of pneumoconiosis which is of very common occurrence in coal-miners and with which tuberculosis is closely associated. It may well be, however, that this infection acts indirectly, producing in the presence of dust a type of collagen, the presence of which causes a reaction in rheumatoid subjects.

\section{SUMMARY}

Lung lesions are described in 16 coal-miners with rheumatoid arthritis.

Nodules having a distinctive gross appearance correspond with the radiographic round opacities described by Caplan. These "rheumatoid" pneumoconiotic nodules contain necrotic collagen and dust. Tuberculosis was present in several cases. A non-specific inflammation was also found. This is believed to be the "rheumatoid" component.
The reasons for the pneumoconiotic lung being vulnerable to the " rheumatoid" process are $\overrightarrow{\vec{\rho}}$ discussed.

The evidence indicates that there is not a direct increased reaction to the dust.

It is suggested that coal-miners with rheumatoid $\vec{\sigma}$ arthritis react abnormally to the collagen produced in infective pneumoconiosis.

Our thanks are due to Dr. A. Caplan for radiological reports, Dr. Scott Thomson and Dr. D. G. $\vec{\omega}$ Davies for examination for tubercle bacilli, Mr. ? H. R. S. Harley, who obtained the biopsies, Dr. J. C. $\overrightarrow{\times}$ Gilson for permission to include Case 16, several col- $\vec{\circ}$ leagues for clinical and other data, Mr. J. P. Napper, who prepared the illustrations, and the Medical Re- $\overrightarrow{0}$ search Council for a grant for technical assistance.

\section{REFERENCES}

Caplan, A. (1953). Thorax, 8, 29

Christie, G. S. (1954). Aust. Ann. Med., 3, 49.

Colinet, E. (1950). Acta physiother. rheum. Belg., 5, 185.

(1953). Ibid., 8, 37.

Collins, D. H. (1937). J. Path. Bact., 45, 97. Collins, D. H. (1937). J. Path. Bact., 45, 97.
Ellman, P., Cudkowicz, L., and Elwood, J. S. (1954). 'J. clin. Path., G
7, 239.

Gruenwald, P. (1948). Arch. Path., Chicago, 46, 59.

Kellgren, J. H. (1952). Brit. med. J., 1, 1152 .

and Ball, J. (1950). Ann. rheum. Dis., 9, 48. and Ball, J. (1950). Ann. rheum. Dis., 9, 48.
Miall, W. E., Caplan, A., Cochrane, A. L., Kilpatrick, G. S., and $\frac{\text { C. }}{\text { Oldham,.P. D. (1953). Brit. med. J., 2, 1231. }}$

Rosenberg, E. F., Baggenstoss, A. H., and Hench, P. S. (1944). Ann. intern. Med., 20, 903.

Simson, F. W.( 1935). J. Path. Bact., 40, 37. 